\title{
FAKTOR YANG BERHUBUNGAN DENGAN PEMBERIAN ASI EKSKLUSIF DI WILAYAH KERJAPUSKESMAS KARANG INTAN 1 TAHUN 2020
}

\author{
Eka Fuziarti' ${ }^{1}$, Hj. Isnaniah, S.ST.,M.Pd²; Yuniarti, SKM.,M.PH ${ }^{3}$ \\ Poltekkes Kemenkes Banjarmasin Jurusan Kebidanan \\ Jl. H. Mistar Cokrokusumo No.1A Banjarbaru Kalimantan Selatan 70714 \\ E-mail: ekafuzi1@gmail.com¹, isnaniahkeb09@gmail.com², yuniartifaathir@gmail.com³
}

\begin{abstract}
Abstrack: Factors Related To Exclusive Breastfeeding In The Working Area Of Karang Intan I Health Center In 2020: Exclusive breastfeeding is breast milk that is given to infants since it is approved for up to 6 months which is added or replaced with other food or drinks Data from the Karang Intan 1 public health center in 2018 as many 11 babies (20\%) received exclusive breastfeeding from 78 babies. Factors causing failure in exclusive breastfeeding by many things, including self-efficacy, family support, and support of health workers. The purpose of study was to study the factors associated with exclusive breastfeeding in the working area of Karang Intan Public Health Center in 2020. This research method uses analytic survey design using cross sectional. The population in study was all mothers who had babies aged $\geq 6-12$ months and took samples using 92 samples of saturated results. The instrument used was a questionnaire. Data analysis used the Chi-Square test with $\alpha=0.05 \%$. The results were obtained from 92 respondents who did not provide exclusive breastfeeding as 48 respondents (52.2\%), mothers who had self-efficacy as many as 42 respondents (45.7\%), mothers who had family support as 47 respondents (51.1\%) ), and mothers who have the support of health workers as 53 respondents (57.6\%). Chi Square Test results indicate there was relationship between maternal self-efficacy with exclusive breastfeeding value $\rho 0,000(\rho<\alpha 0.05)$, there is a relationship of family support with exclusive breastfeeding value $\rho 0.012$ ( $\rho<\alpha 0.05)$, and there is a relationship of support Health workers with exclusive breastfeeding support value of $\rho 0,000(\rho<\alpha$ 0.05). Conclusion, there in a correlation between mother's selfefficacy, family support, and health support with exclusive breastfeeding assistance in the working area of Karang Intan I Public Health Center 2020.
\end{abstract}

Keywords: Exclusive breastfeeding, self-efficacy, family support, and support of health workers 
Ringkasan: Faktor Yang Berhubungan Dengan Pemberian Asi Eksklusif Di Wilayah Kerja Puskesmas Karang Intan 1 Tahun 2020: ASI eksklusif adalah ASI yang diberikan kepada bayi sejak dilahirkan sampai dengan 6 bulan tanpa menambahkan atau mangganti dengan makanan atau minuman lain. Data dari Puskesmas Karang Intan 1 pada tahun 2018 sebanyak 11 bayi (20\%) yang mendapat ASI ekslusif dari 78 bayi. Faktor penyebab kegagalan dalam pemberian ASI eksklusif dipengaruhi oleh banyak hal, antara lain efikasi diri, dukungan keluarga, dan dukungan tenaga kesehatan. Tujuan penelitian adalah untuk mengetahui Faktor yang berhubungan dengan pemberian ASI ekslusif di wilayah kerja Puskesmas Karang Intan 1 Tahun 2020. Metode penelitian ini menggunakan rancangan survei analitik dengan pendekatan cross sectional. Populasi dalam penelitian seluruh ibu yang memiliki bayi usia $\geq 6-12$ bulan dan pengambilan sampel menggunakan teknik sampel jenuh berjumlah 92 orang. Instrumen yang digunakan adalah kuesioner. Analisa data menggunakan uji Chi-Square dengan $\alpha=0,05 \%$. Hasil penelitian didapatkan dari 92 responden yang tidak memberikan ASI Eksklusif 48 responden (52,2\%), ibu yang memiliki efikasi diri tinggi 42 responden (45,7\%), ibu yang memiliki dukungan keluarga 47 responden $(51,1 \%)$, dan ibu yang memiliki dukungan tenaga kesehatan 53 responden $(57,6 \%)$. Hasil Uji Chi Square menunjukkkan ada hubungan efikasi diri ibu dengan pemberian ASI Eksklusif nilai $\rho 0,000(\rho<\alpha 0,05)$, ada hubungan dukungan keluarga dengan pemberian ASI Eksklusif nilai $\rho 0,012(\rho<\alpha 0,05)$, dan ada hubungan dukungan tenaga kesehatan dengan pemberian ASI Eksklusif nilai $\rho 0,000(\rho<\alpha 0,05)$. Kesimpulan penelitian ini ada hubungan efikasi diri ibu, dukungan keluarga, dan dukungan tenaga kesehatan dengan pemberian ASI Eksklusif di Wilayah Kerja Puskesmas Karang Intan I Tahun 2020.

Kata Kunci: Pemberian ASI Eksklusif, efikasi diri, dukungan keluarga, dan dukungan tenaga kesehatan 


\section{PENDAHULUAN}

Cakupan pemberian ASI ekslusif belum mencapai target nasional yang telah ditetapkan Kementrian Kesehatan (Kemenkes) Republik Indonesia yaitu sebesar $80 \%$. Berdasarkan data dari Profil Kesehatan Republik Indonesia selama 3 tahun berturut-turut yaitu tahun 2016, 2017 dan 2018 cakupan ASI ekslusif di Indonesia mengalami kenaikan dan penurunan. Cakupan ASI eklslusif di Indonesia pada tahun 2016 berada pada angka 2.576.039 (54,0\%) (Kementerian kesehatan RI, 2016). Kemudian pada tahun 2017 cakupan ASI ekslusif di Indonesia mengalami penurunan yaitu menjadi 1.695 .902 $(35,73 \%)$ (Kementerian kesehatan RI, 2017). Sedangkan pada tahun 2018 cakupan ASI ekslusif di Indonesia mengalami kenaikan yaitu 3.063.838 (65,16\%) (Kementerian kesehatan RI, 2018).

Cakupan ASI ekslusif di Provinsi Kalimantan pada tahun 2016 Selatan adalah 57,7\%.(Dinas Kesehatan Provinsi Kalimantan Selatan, 2016). Tahun 2017 mengalami penurunan yaitu 36,78\% (Dinas Kesehatan Provinsi Kalimantan Selatan, 2017). kemudian pada tahun 2018 mengalami kenaikan yaitu 55,31\% (Dinas Kesehatan Provinsi Kalimantan Selatan, 2018).

Cakupan ASI ekslusif di Kabupaten Banjar tahun 2016 sebesar 39,5\% bayi yang mendapatkan ASI ekslusif. Tahun 2017 mengalami kenaikan sebesar $41,8 \%$ bayi yang mendapatkan ASI ekslusif, kemudian tahun 2018 mengalami peningkatan sebesar $46,3 \%$ bayi yang mendapatkan ASI ekslusif (Dinas Kesehatan Kabupaten Banjar, 2018 hal.164).

Data dari Dinas Kesehatan Kabupaten Banjar menyatakan cakupan ASI ekslusif Puskesmas Karang Intan 1 menduduki peringkat kelima terendah setelah Puskesmas Paramasan, Puskesmas Astambul, Puskesmas Simpang Empat 1, dan Puskesmas Mataraman. Puskesmas Karang Intan 1 pada tahun 2016 cakupan ASI ekslusif sebanyak 19 bayi (17\%) dari 155 bayi, pada tahun 2017 sebanyak $13(11,5 \%)$ yang mendapat ASI ekslusif dari 113 bayi, dan pada tahun 2018 sebanyak 11 (20\%) yang mendapat ASI ekslusif dari 78 bayi (Dinas Kesehatan Kabupaten Banjar, 2018). Berdasarkan hasil wawancara dengan bidan dan ahli gizi di Wilayah Kerja Puskesmas Karang Intan 1 pada tanggal 21 November 2019 bahwa cakupan ASI ekslusif rendah dikarenakan pengetahuan, ASI yang sedikit keluar, perilaku ibu dalam memberikan ASI eksklusif, kurangnya dukungan keluarga, pola makan yang belum terpenuhi. Hasil studi pendahuluan yang telah dilakukan oleh peneliti di Wilayah Kerja Puskesmas Karang Intan1 dengan 10 ibu yang memiliki bayi didapatkan 4 orang ibu menyusui yang memberikan ASI eksklusif sedangkan 6 orang lainnya memberikan ASI ditambah susu formula. Alasan dari ibu yang memberikan tambahan susu formula, 4 orang mengatakan kurangnya informasi dan dukungan keluarga, dan 2 orang lainnya mengatakan hanya sedikit ASI yang keluar sehingga ibu tidak yakin untuk memberikan ASI esksklusif kepada bayinya. Ibu takut bayinya tidak kenyang sehingga memberikan tambahan susu formula. Berdasarkan uraian diatas maka 
peneliti tertarik untuk meneliti " Faktor Yang Berhubungan Dengan Pemberian ASI Eksklusif Di Wilayah Kerja Puskesmas Karang Intan 1 Tahun 2020".

\section{METODE}

Jenis penelitian ini menggunakan metode survei analitik dengan pendekatan yang digunakan adalah cross sectional. Populasi pada penelitian ini adalah seluruh ibu yang mempunyai bayi usia $\geq 6-12$ bulan berjumlah 92 ibu yang ada diwilayah kerja Puskesmas Karang Intan 1. Teknik pengambilan sampel pada penelitian ini menggunakan Sampling Jenuh.

Penelitian ini dilakukan di wilayah kerja Puskesmas Karang Intan 1 pada bulan November 2019 s/d April 2020.

Pengumpulan data dilakukan berdasarkan data primer yaitu data yang diperoleh secara langsung dengan melakukan sendiri pengumpulan (wawancara, dan kuesioner) terhadap objek. Data masih merupakan data mentah yang belum mengalami proses analisi (Ariani, 2014, hal. 77). Data yang digunakan dalam penelitian ini adalah data hasil kuesioner yang diisi oleh responden.

\section{HASIL DAN PEMBAHASAN}

a. Analisis Univariat

1) Pemberian ASI Eksklusif

\section{Tabel 4.4}

Distribusi Frekuensi Responden Berdasarkan Pemberian ASI Eksklusif di Wilayah Kerja Puskesmas Karang Intan I Tahun 2020

\begin{tabular}{c|c|c|c}
\hline \multirow{2}{*}{ No. } & Pemberian ASI & \multicolumn{2}{|c}{ Jumlah } \\
\cline { 3 - 4 } & Eksklusif & $f$ & $\%$ \\
\hline 1. & Memberikan & 44 & 47,8 \\
\hline 2. & Tidak Memberikan & 48 & 52,2 \\
\hline \multicolumn{2}{c}{ Total } & 92 & 100,0 \\
\hline
\end{tabular}

Sumber: Data Primer

Berdasarkan tabel 4.4 menunjukan dari 92 responden, yang tidak memberikan ASI Eksklusif yaitu 48 responden (52,2 \%).

Menurut teori Wiji (2013, hal. 27) ASI Eksklusif adalah menyusui bayi secara murni, yang dimaksud secara murni adalah bayi hanya diberi ASI saja selama 6 bulan tanpa tambahan cairan apapun, seperti susu formula, jeruk, madu, air teh, air putih dan tanpa pemberian makanan tambahan lain, seperti pisang, bubur susu, biskuit, bubur atau nasi tim. Penyebab umum kegagalan pemberian ASI Eksklusif adalah ibu bekerja, tidak ada dukungan dari 
keluarga, tekhnik menyusui yang tidak tepat dan mitos ASI encer tidak baik untuk bayi.

Hasil dari penelitian ini didapatkan dari 92 responden yang memiliki bayi, yang tidak memberikan ASI Eksklusif yaitu 48 responden (52,2 \%). Menurut Astutik (2014 hal.94), mengatakan bahwa faktor-faktor yang mempengaruhi dalam keberhasilan ASI Eksklusif yaitu sosial budaya, psikologis, kondisi ibu, kondesi bayi, dan dukungan tenaga kesehatan. Jika seorang bayi tidak diberikan ASI Eksklusif dan diganti dengan susu formula, maka bayi tidak mendapatkan kekebalan, serta akan kekurangan gizi, dengan tidak adanya antibodi maka bayi akan mudah terserang berbagai macam penyakit serta menurut Wiji (2013, hal. 64) masalah menyusui yang sering ditemui pada ibu yaitu kurang informasi tentang ASI Eksklusif, ibu bekerja, puting susu lecet, abses payudara, dan produksi ASI kurang.

2) Efikasi Diri

Tabel 4.5

Distribusi Frekuensi Responden Berdasarkan Efikasi Diri di Wilayah Kerja Puskesmas Karang Intan I Tahun 2020

\begin{tabular}{|c|c|c|c|}
\hline \multirow{2}{*}{ No. } & \multirow{2}{*}{ Efikasi Diri } & \multicolumn{2}{|c|}{ Jumlah } \\
\hline & & $f$ & $\%$ \\
\hline 1. & Tinggi & 42 & 45,7 \\
\hline 2. & Rendah & 50 & 54,3 \\
\hline & Total & 92 & 100,0 \\
\hline
\end{tabular}

Sumber: Data Primer

Berdasarkan tabel 4.5 menunjukan dari 92 responden, yang memiliki efikasi rendah dalam pemberian ASI Eksklusif yaitu 50 responden (54,3\%).

Menurut penelitian yang dilakukan oleh Rahayu (2018) Efikasi diri adalah keyakinan yang dimiliki oleh individu terhadap suatu hal yang belum dilakukan sehingga dapat menjadi indikator seseorang dalam menentukan pilihan dan memotivasi diri sendiri agar berhasil dalam mencapai tujuan tindakan yang akan dilakukan. Efikasi diri yang tinggi menunjukkan rasa keyakinan yang tinggi dalam diri seorang ibu dalam hal menyusui.

Hasil penelitian ini dari 92 responden, yang memiliki efikasi diri yang rendah dalam pemberian ASI Eksklusif yaitu 50 responden (54,3\%) dan ibu yang efikasi diri yang tinggi dalam pemberian ASI Eksklusif yaitu 42 responden $(45,7 \%)$, lbu yang memiliki efikasi diri yang rendah dalam pemberian ASI Eksklusif karena ibu tidak percaya diri dapat menyusui tanpa menggunakan susu formula sebagai tambahan dan seperti ibu 
tidak pecaya diri dalam melanjutkan pemberian ASI sampai 2 tahun, dari hasil penelitian ini didapatkan bahwa semakin rendah kepercayaan diri ibu maka semakin tidak yakin dalam pemberian ASI Eksklusif. Sedangkan ibu yang memiliki efikasi diri yang tinggi akan memiliki keyakinan yang kuat sehingga berhasil memberikan ASI eksklusif kepada bayinya.

Menurut penelitian yang dilakukan oleh Ratnasari (2018), kegagalan dalam ibu menyusui sering terjadi, salah satunya ibu tidak percaya diri dalam menyusui bayinya. Sedikit saja ibu merasa ragu atau kurang percaya diri dapat menyebabkan kerja hormone oksitosin melambat, akibatnya ASI yang keluar menjadi sedikit. Pengalaman dalam menyusui ASI Eksklusif dapat memberikan pengaruh besar pada efikasi diri seseorang karena didasarkan pada pengalaman-pengalaman pribadi secara nyata yang berupa keberhasilan dan kegagalan. Pengalaman keberhasilan akan menaikkan efikasi diri individu, sedangkan pengalaman kegagalan akan menurunkannya.

3) Dukungan Keluarga

Tabel 4.6

Distribusi Frekuensi Responden Berdasarkan Dukungan Keluarga di Wilayah Kerja Puskesmas Karang Intan I Tahun 2020

\begin{tabular}{|c|c|c|c|}
\hline \multirow{2}{*}{ No. } & \multirow{2}{*}{$\begin{array}{c}\text { Dukungan } \\
\text { Keluarga }\end{array}$} & \multicolumn{2}{|c|}{ Jumlah } \\
\hline & & $f$ & $\%$ \\
\hline 1. & Mendukung & 47 & 51,1 \\
\hline 2. & Tidak Mendukung & 45 & 48,9 \\
\hline & Total & 92 & 100,0 \\
\hline
\end{tabular}

Berdasarkan tabel 4.6 menunjukan dari 92 responden, yang memiliki keluarga tidak mendukung dalam pemberian ASI Eksklusif yaitu 45 responden (48,9\%).

Menurut teori Puspitaningrum (2017, hal. 128) dukungan keluarga adalah sikap, tindakan dan penerimaan keluarga. Keluarga juga berfungsi sebagai sistem pendukung bagi anggotanya dan anggota keluarga memandang bahwa orang yang bersifat mendukung selalu siap memberikan pertolongan dan bantuan jika diperlukan.

Hasil penelitian ini didapatkan dari 92 responden, sebanyak 45 respoden $(48,9 \%)$ yang tidak mendapatkan dukungan keluarga, dan sebanyak 47 respoden $(51,1 \%)$ yang mendapatkan dukungan keluarga. Menurut Harnilawati (2013, hal. 27) keluarga memiliki beberapa jenis dukungan yaitu dukungan informasi meliputi pemberian nasihat, pengarahan, ide-ide atau informasi lainnya yang diperlukan, dukungan 
emosional dukungan ini merupakan dukungan simpati dan empati, cinta, kepercayaan dan penghargaan, bantuan instrumental bantuan bentuk ini bertujuan mempermudah seseorang untuk melakukan aktivitasnya berkaitan dengan permasalahan-permasalahan yang dihadapinya atau menolong secara langsung kesulitan yang dihadapinya, dan bantuan penilaian ini bisa positif dan negatif yang pengaruhnya sangat berarti bagi seseorang.

4) Dukungan Tenaga Kesehatan

Tabel 4.7

Distribusi Frekuensi Responden Berdasarkan Dukungan Tenaga Kesehatan di Wilayah Kerja Puskesmas Karang Intan I Tahun 2020

\begin{tabular}{|c|c|c|c|}
\hline & \multirow{2}{*}{$\begin{array}{c}\text { Dukungan Tenaga } \\
\text { Kesehatan }\end{array}$} & \multicolumn{2}{|c|}{ Jumlah } \\
\hline & & $f$ & $\%$ \\
\hline 1. & Mendukung & 53 & 57,6 \\
\hline 2. & Tidak Mendukung & 39 & 42,4 \\
\hline & Total & 92 & 100,0 \\
\hline
\end{tabular}

Berdasarkan tabel 4.7 menunjukan dari 92 responden, tenaga kesehatan yang tidak mendukung dalam pemberian ASI Eksklusif yaitu 39 responden $(42,4 \%)$.

Menurut teori Afifah (2007) dukungan tenaga kesehatan sangat penting dalam melindungi, meningkatkan dan mendukung usaha menyusui. Bidan sebagai salah satu tenaga kesehatan memiliki peran yang sangat penting dalam menunjang pemberian ASI Eksklusif. Peran bidan dalam membantu ibu dalam memberikan ASI dengan baik dan mencegah masalah yang biasanya sering dialami ibu menyusui (Septikasari, 2018, hal. 35).

Hasil penelitian ini didapatkan dari 92 responden, tenaga kesehatan yang tidak mendukung dalam pemberian ASI Eksklusif yaitu 39 responden $(42,4 \%)$ dan tenaga kesehatan yang mendukung dalam pemberian ASI Eksklusif yaitu 53 responden (57,6\%). Menurut Juliani Sri (2018) faktor yang mempengaruhi keberhasilan ibu memberikan ASI Eksklusif antara lain adalah faktor karakteristik ibu yaitu pendidikan, pengetahuan, faktor predisposisi meliputi pengetahuan, sikap, minat, faktor pendukung meliputi sarana pelayanan kesehatan, pendapatan keluarga, ketersediaan waktu, kesehatan ibu, faktor pendorong meliputi dukungan keluarga, dan dukungan tenaga kesehatan. Dukungan tenaga kesehatan sangat berperan dalam pemberian ASI Eksklusif dikarenakan jika tenaga kesehatan sering memberikan informasi serta penyuluhan 
pendidikan tentang ASI Eksklusif maka para ibu yang memiliki bayi akan memberikan ASI Eksklusif kepada bayinya.

b. Analisis Bivariat

1) Hubungan Efikasi Diri dengan Pemberian ASI Eksklusif

Tabel 4.8

Hubungan Efikasi Diri dengan Pemberian ASI Eksklusifdi Wilayah Kerja Puskesmas Karang Intan I Tahun 2020

\begin{tabular}{c|c|c|c|c|c|c}
\hline \multirow{2}{*}{$\begin{array}{c}\text { Efikasi Diri } \\
\text { Ibu }\end{array}$} & \multicolumn{6}{|c}{ Pemberian ASI Ekslusif } \\
\cline { 2 - 7 } & $f$ & $\%$ & $f$ & $\%$ & $f$ & $\%$ \\
\hline Tinggi & 31 & 73,8 & 11 & 26,2 & 42 & 100,0 \\
\hline Rendah & 13 & 26,0 & 37 & 74,0 & 50 & 100,0 \\
\hline \multicolumn{6}{|c}{ Uji Chi Square $\rho 0,000(\rho<\alpha 0,05)$} \\
\hline
\end{tabular}

Sumber: Data Primer

Berdasarkan tabel 4.8 hasil uji statistik menggunakan Chi Square diperoleh nilai $\rho$ 0,000 $(\rho<\alpha 0,05)$ artinya ada hubungan efikasi diri ibu dengan pemberian ASI Eksklusif di Wilayah Kerja Puskesmas Karang Intan I Tahun 2020.

Berdasarkan penelitian yang dilakukan oleh Vitasari, dkk, (2018). Efikasi diri dalam menyusui akan menentukan apakah ibu akan menyusui bayinya atau tidak, seberapa besar usaha ibu untuk menyusui dan bagaimana ibu mengatasi semua kesulitan yang dihadapi saat menyusui, faktor yang mempengaruhi ibu tidak memberikan ASI kepada bayi diantaranya kondisi ibu yang sakit, lelah, kurang yakin atau tidak percaya diri dapat menggnggu pemberian ASI Eksklusif

Hasil penelitian ini ditemukan bahwa dari 50 ibu yang memiliki efikasi rendah yang tidak memberikan ASI Eksklusif yaitu sebanyak 37 responden $(74,0 \%)$ karena efikasi diri atau kepercayaan diri ibu rendah sehingga ibu tidak merasa yakin dalam memberikan ASI Eksklusif. Ibu yang memiliki efikasi rendah cendrung berfokus pada pemikiranpemikiran negatif dalam menyusui seperti ibu khawatir karena ASI sedikit keluar sehingga ibu tidak memberikan ASI kepada bayi dan kurangnya usaha ibu dalam menghadapi kesulitan saat menyusui akan membuat ibu menghentikan pemberian ASI eksklusif dan memilih memberikan susu formula. 
2) Hubungan Dukungan Keluarga dengan Pemberian ASI Eksklusif

Tabel 4.9

Hubungan Dukungan Keluarga dengan Pemberian ASI EksklusifDi Wilayah Kerja Puskesmas Karang Intan I Tahun 2020

\begin{tabular}{l|c|c|c|c|c|c}
\hline \multirow{2}{*}{$\begin{array}{c}\text { Dukungan } \\
\text { Keluarga }\end{array}$} & \multicolumn{6}{|c}{ Pemberian ASI Ekslusif } \\
\cline { 2 - 7 } & Memberikan & $\begin{array}{c}\text { Tidak } \\
\text { Memberikan }\end{array}$ & \multicolumn{2}{c}{ Total } \\
\cline { 2 - 7 } & $f$ & $\%$ & $f$ & $\%$ & $f$ & $\%$ \\
\hline Mendukung & 29 & 61,7 & 18 & 38,3 & 47 & 100,0 \\
\hline $\begin{array}{l}\text { Tidak } \\
\text { Mendukung }\end{array}$ & 15 & 33,3 & 30 & 66,7 & 45 & 100,0 \\
\hline & Uji Chi Square 0 0, 012 $(\rho<\alpha 0,05)$ \\
\hline Sumber: Data Primer
\end{tabular}

Berdasarkan tabel 4.9 hasil uji statistik menggunakan Chi Square diperoleh nilai $\rho$ 0,012 $(\rho<\alpha 0,05)$ artinya ada hubungan dukungan keluarga dengan pemberian ASI Eksklusif di Wilayah Kerja Puskesmas Karang Intan I Tahun 2020.

Dukungan keluarga yang baik dapat memberikan motivasi yang baik, namun apabila keluarga tidak mendukung dikarenakan repot atau mitos yang salah, maka ibu juga akan menjadi tidak semangat dalam memberikan ASI Eksklusif (Widuri, 2013, hal.38). Keluarga memberikan kontribusi yang besar terhadap keinginan ibu untuk menyusui bayi selain memberikan pengaruh yang kuat untuk pengambilan keputusan untuk tetap menyusui (Astutik, 2014 hal.108).

Hasil penelitian ini ditemukan bahwa dari 45 responden memiliki keluarga yang tidak mendukung sebanyak 30 responden $(66,7 \%)$ yang tidak memberikan ASI Eksklusif. Hal ini terjadi karena penyebab umum kegagalan pemberian ASI Eksklusif salah satunya adalah tidak ada dukungan dari keluarga dalam pemberian ASI Eksklusif. Hal ini dikarenakan keluarga bekerja sehingga jarang dirumah sehingga ibu harus mengurus dan memperhatikan diri sendiri, serta masih adanya kebudayaan yang memberikan air zam-zam dan kurma setelah bayi lahir dikarenakan kurangnya informasi keluarga tentang ASI Eksklusif. Apabila keluarga tidak mendukung maka ibu akan menjadi tidak semangat dalam memberikan ASI Eksklusif.

Penelitian ini sejalan dengan Vitasari, dkk (2018) hasil uji menggunakan Chi Square diperoleh nilai $\rho 0,000(\rho<\alpha 0,05)$ dapat disimpulkan bahwa ada hubungan antara dukungan keluarga terhadapat 
pemberian ASI Eksklusif. Dukungan keluarga merupakan faktor eksternal yang paling berpengaruh terhadap keberhasilan menyusui. Adanya dukungan keluarga dapat meningkatkan pemberian ASI Eksklusif kepada bayinya. Tanpa dukungan keluarga ibu akan merasa berjuang sendiri dalam menyusui sehingga ibu akan mudah menyerah memberikan ASI Eksklusif apalagi disaat ibu harus menghadapi berbagai masalah yang muncul saat proses menyusui.

3) Hubungan Dukungan Tenaga Kesehatan dengan Pemberian ASI Eksklusif

Tabel 4.10

Hubungan Dukungan Tenaga Kesehatan dengan Pemberian ASI

Eksklusif di Wilayah Kerja Puskesmas Karang Intan I Tahun 2020

\begin{tabular}{l|c|c|c|c|c|c}
\hline \multirow{2}{*}{$\begin{array}{c}\text { Dukungan } \\
\text { Tenaga } \\
\text { Kesehatan }\end{array}$} & \multicolumn{6}{c}{ Pemberian ASI Ekslusif } \\
\cline { 2 - 7 } & \multicolumn{2}{|c|}{ Memberikan } & \multicolumn{1}{c}{ Tidak Memberikan } & \multicolumn{2}{c}{ Total } \\
\hline Mendukung & 35 & 66,0 & 18 & 34,0 & 53 & 100,0 \\
\hline $\begin{array}{c}\text { Tidak } \\
\text { Mendukung }\end{array}$ & 9 & 23,1 & 30 & 76,9 & 39 & 100,0 \\
\hline
\end{tabular}

Sumber: Data Primer

Berdasarkan tabel 4.10 hasil uji statistik menggunakan Chi Square diperoleh nilai $\rho$ 0,000 $(\rho<\alpha 0,05)$ artinya ada hubungan dukungan tenaga kesehatan dengan pemberian ASI Eksklusif di Wilayah Kerja Puskesmas Karang Intan I Tahun 2020.

Dukungan tenaga kesehatan yang baik dapat memberikan bimbingan dan penyuluhan serta wawancara kepada ibu untuk memberikan ASI Eksklusif (Febria, 2019 hal.23). Peran bidan dalam membantu ibu dalam memberikan ASI dengan baik dan mencegah masalah yang biasanya sering dialami ibu menyusui antara lain konseling saat kehamilan, melakukan perawatan payudara, inisiasi menyusui dini (IMD), promosi tentang ASI Eksklusif (Septikasari, 2018, hal. 38).

Hasil penelitian ini ditemukan bahwa dari 39 responden yang tidak mendapat dukungan tenaga kesehatan sebanyak 30 responden $(76,9 \%)$ yang tidak memberikan ASI Eksklusif. Hal ini sejalan dengan teori-teori yang mempengaruhi pemberian ASI Eksklusif salah satunya yaitu dukungan dari tenaga kesehatan. 
Hasil penelitian ini sejalan dengan penelitian yang dilakukan oleh Juliani (2018) Hasil uji statistik menggunakan Chi Square diperoleh nilai $p$ $=0,007(p<a=0,05)$ artinya ada hubungan antara dukungan tenaga kesehatan dengan pemberian ASI Eksklusif di Wilayah Kerja Puskesmas Darussalam Kecamatan Medan Petisah. Dukungan tenaga kesehatan sangat berperan dalam pemberian ASI Eksklusif dikarenakan jika tenaga kesehatan sering memberikan informasi, memberikan dukungan emosinal, serta penyuluhan pendidikan tentang ASI Eksklusif maka para ibu-ibu yang memiliki bayi akan memberikan ASI Eksklusif kepada bayinya.

\section{KESIMPULAN DAN SARAN}

Ada hubungan antara efikasi diri ibu dengan pemberian ASI Eksklusif ( $\rho$ $0,000<\alpha 0,05)$, dukungan keluarga dengan pemberian ASI Eksklusif $(\rho$ $0,012<\alpha 0,05)$, dan dukungan tenaga kesehatan dengan pemberian ASI Eksklusif $(\rho 0,000<\alpha 0,05)$.

Saran :

1. Bagi Tenaga Kesehatan (Bidan)

Diharapkan lebih meningkatkan lagi promosi kesehatan tentang ASI Eksklusif bagi ibu hamil, bersalin, nifas, dan ibu menyusui sampai umur 6 bulan. Promosi kesehatan tidak hanya berfokus pada ibu saja tetapi juga pada keluarga, seperti suami, orang tua atau mertua dalam mendukung pemberian ASI Eksklusif.

2. Bagi Responden

Diharapkan ibu lebih menambah wawasan mengenai pentingnya pemberian ASI Eksklusif bagi bayi untuk pertumbuhan dan perkembangan bayinya bisa melalui media cetak maupun elektronik, dari petugas kesehatan, serta mengikuti kegiatan posyandu setiap bulan.

\section{DAFTAR PUSTAKA}

1. Ariani, A, P. (2014). Aplikasi Metodelogi penelitian Kebidanan Dan kesehatan reproduksi. Yogyakarta: Nuha Medika.

2. Astutik, R. Y. (2010). Payudara dan Laktasi. Jakarta : Salemba Medika

3. Dinas Kesehatan Kabupaten Banjar. (2016). Profil Kesehatan Kabupaten Banjar Tahun 2016. Martapura: Dinkes Kab.Banjar

4. Tahun 2017. Martapura: Dinkes Kab.Banjar

5. (2018). Profil Kesehatan Kabupaten Banjar

Tahun 2018. Martapura: Dinkes Kab.Banjar 
6. Dinas Kesehatan Provinsi Kalimantan Selatan. (2016). Profil Dinas Kesehatan Provinsi Kalimantan Selatan 2016. Kalimantan Selatan. Banjarmasin: Dinkes Provinsi Kalimantan Selatan

7. (2017). Profil Dinas Kesehatan Provinsi Kalimantan Selatan 2017. Kalimantan Selatan. Banjarmasin: Dinkes Provinsi Kalimantan Selatan

8. (2018). Profil Dinas Kesehatan Provinsi Kalimantan Selatan 2018. Kalimantan Selatan. Banjarmasin: Dinkes Provinsi Kalimantan Selatan

9. Febria, Z. (2019). Faktor yang Berhubungan dengan Pemberian ASI Eksklusif di Wilayah Kerja Puskesmas Astampul Tahun 2019. Poltekkes Kemenkes Banjarmasin

10. Harnilawati. (2013). Konsep dan Proses Keperawatan Keluarga. Sulsel: Penerbit Pustaka As Salam

11. Juliani, S dan Arma, N. (2018). Hubungan Pengetahuan, Sikap, Dan Dukungan Tenaga Kesehatan Dengan Keberhasilan Asi Eksklusif Di Wilayah Kerja Puskesmas Darussalam Kecamatan Medan Petisah (Internet). Tersedian dalam <http://ejurnal.helvetia.ac.id> (diakses pada tanggal 10 November 2019).

12. Kementerian Kesehatan Republik Indonesia. (2016). Profil Kesehatan Indonesia 2016. Jakarta: Kemenkes Rl. <www.depkes.go.id> (diakses pada tanggal 11 November 2019).

13. (2017). Profil Kesehatan Indonesia 2017. Jakarta: Kemenkes RI <www.depkes.go.id $>$ (diakses pada tanggal 10 November 2019).

14. . (2018). Profil Kesehatan Indonesia 2018. Jakarta: Kemenkes $\mathrm{Rl}<$ www.depkes.go.id $>$ (diakses pada tanggal 10 November 2019).

15. Puspitaningrum, I. (2017). Peningkatan Kualitas Personal dan Profesional Perawat Melalui Pengembangan Keprofesian Berkelanjutan (PKB). Yogyakarta : CV Budi Utama

16. Rahayu, D. (2018). Hubungan Breastfeeding Self Efficacy dengan Keberhasilan Pemberian ASI Eksklusif (Internet). Tersedia dalam $<$ http://ejurnaladhkdr.com $>$ (diakses pada tanggal 11 November 2019).

17. Ratnasari, R, D. (2018). Kepercayaan Diri Ibu pada Pemberian ASI Eksklusif di Wilayah Desa Sentolo Kulonprogo Yogyakarta (Internet). Tersedia dalam <http://digilib.unisayogya.ac.id $>$ (diakses pada tanggal 11 November 2019).

18. Septikasari, M (2018). Status Gizi Anak dan faktor yang Mempengaruhi. Yogyakarta: UYN Press

19. Vitasari, D, dkk. (2018). Hubungan Dukungan Keluarga Terhadap Efikasi Diri Ibu Menyusui dalam Memberikan ASI Eksklusif (Internet). 
Tersedia dalam <http://jom.unri.ac.id $>$ (diakses pada tanggal 11 November 2019).

20. Widuri, Hesti. (2013). Cara Mengelola ASI Eksklusif Bagi Ibu Bekerja. Yogyakarta: Gosyen Publishing

21. Wiji, Rizki Natia. (2013). ASI dan Panduan Ibu Menyusui. Yogyakarta: Nuha Medika 